\title{
Effect of storage periods and packaging materials on the proximate and chemical properties of frozen blue whiting (Micromesistius poutassou) at different exposure time
}

\author{
A. E. Odiko* and E. Joseph \\ Department of Aquaculture and Fisheries Management, Faculty of Agriculture, University of Benin, Benin City. \\ NIGERIA \\ "Corresponding author. E-mail: andress.odiko@uniben.edu
}

Received: May 17, 2017; Revised received: July 16, 2017; Accepted: August 28, 2017

\begin{abstract}
This research seeks to determine the effect of storage periods and packaging materials on the proximate and chemical properties of frozen blue whiting (Micromesistius poutassou) at different exposure time - 0 hour, 2 hours and 4 hours, on arrival at the laboratory. Frozen M. poutassou were bought and stored in a commercial cold room for 12 weeks at $-10^{\circ} \mathrm{C}$ and packed in different packaging materials (Ziploc bag, foil paper and carton) with unwrapped samples for analysis which lasted 90 days and was conducted every 14 days to measure the moisture, protein, fat, ash, fibre and nitrogen free extract (NFA) content of the fish sample as well as iodine value, peroxide value, saponification value, acid value, free fatty acid and hydroxyl value of fish oil. The result clearly reveals that during storage, the different packaging materials showed significantly $(p<0.05)$ decreasing trend in protein, lipid, ash, fibre and NFA content with increasing storage period and time of analysis except for the moisture content that showed opposite trend. For the chemical properties, the saponification value, peroxide value, free fatty acid, acid value and hydroxyl value showed significantly $(p<0.05)$ increasing trend in the different packaging materials with increasing storage period and time of analysis. While the iodine value decreased with increasing period of storage and time of analysis; the iodine, saponification, peroxide and hydroxyl values were not within the acceptable limits.
\end{abstract}

Keywords: Chemical properties, Frozen storage, Micromesistius poutassou, Proximate composition

\section{INTRODUCTION}

Fish is one of the most important sources of animal protein available in the tropics and has been widely accepted as good source of protein and other elements for maintenance of healthy body (Andrew, 2001). According to FAO (2016), the world per capita apparent fish consumption increased from an average of $9.9 \mathrm{~kg}$ in the 1960 's to $14.4 \mathrm{~kg}$ in the 1990 's and $20 \mathrm{~kg}$ in 2016, with a projected further increase in subsequent years. This trend will further put more pressure on the wild stock and encourage culture where funds could be made available by governmental and nongovernmental agencies; invariably creating jobs for the teeming unemployed youth or underemployed in Nigeria and in the world. Fish is important to the ever increasing world population, especially in most parts of Africa, as it is the major source of cheap high quality animal protein, contributing about 50 to 60 percent of the animal protein intake of the population especially in rural communities (Ayoola, 2010; Adekoya and Miller, 2004).It has the highest level of easily metabolized protein such as myosin and globulin, polyunsaturated Omega 3-fatty acid (docosahexaenoic acid and eicosapentaenoic acid, vitamins (A, B and C), calcium, iron and essential amino acids when compared to other sources of animal protein such as poultry and beef (Babalola et al., 2015).

Globally, growth in fish supply for human consumption has outpaced population growth in the past five decades, increasing at an average annual rate of $3.2 \%$ in the period 1961-2013, double that of population growth, resulting in increasing average per capita availability. World per capita apparent fish consumption increased from an average of $9.9 \mathrm{~kg}$ in the $1960 \mathrm{~s}$ to $14.4 \mathrm{~kg}$ in the $1990 \mathrm{~s}$ and $19.7 \mathrm{~kg}$ in 2013 , with preliminary estimates for 2014 and 2015 pointing towards further growth beyond $20 \mathrm{~kg}$ as reported by FAO (2016). In addition to the increase in production, other factors that have contributed to rising consumption include reductions in wastage, better utilization, improved distribution channels and growing demand linked to population growth, rising incomes and urbanization. International trade has also played an important role in providing wider choices to consumers. Nigeria spends $\$ 100$ billion (\$302 million) on frozen fish importation annually and the current fish demand consumption in Nigeria stands at over 2.66 million tons per annum, while the present importation rate is over 750,000 metric tons (Oota, 2012). Blue whiting 
(Micromesistius poutassou) is one of the fish species imported into Nigeria, it is popularly known as "kpanla" in the Nigerian market and it is recognized by its bluish colour, long slender shape and lack of barbel. It feed mostly on small crustaceans but large individuals also prey on small fish and cephalopods (Monstad, 2004).

Fish and fishery products quality has become a major source of concern in fish industry all over the world (Huss et al., 2003) because of their short shelf life, high perishability and which also vary due to the variation in species, environmental habitats and feeding habits (Yagoub, 2009). The quality and freshness of fish rapidly deteriorates shortly after capture through microbial and biochemical mechanisms due to enzymatic breakdown of major fish molecules resulting in early quality loss in fresh fish (Al-Jasser and AlJasass, 2014; Rey et al., 2012; FAO, 2005).Live fish is naturally considered to be sterile, but after death the defense mechanism of the fish fails to combat the actions of microorganisms which are found on the skin, gills and alimentary tract, and due to contamination and replication of these microbes; decay occurs and the consumption becomes dangerous ( Mol and Tosun, 2011; Alparslan et al., 2014). Lipids and proteins oxidation are also important factors affecting the quality of frozen fish because they cause fish off-flavour, as the enzymatic hydrolysis of fats by lipases (lipolysis) results in fat deterioration. During this process, lipases split the glycerides forming free fatty acids which are responsible for the common off-flavour, frequently referred to as rancidity and reduction in the oil quality (Huis in't Veld, 1996; FAO, 1986). Non-enzymatic oxidation is caused by heamatin compounds (haemoglobin, myoglobin and cytochrome) catalysis producing hydroperoxides (Fraser and Sumar, 1998).

Preservation of fish can be achieved by various methods but freezing is the easiest and least timeconsuming method of food preservation that allows the retention of the natural colour, flavour, taste, texture allowing lengthy shelf-life, greater convenience, the retention of nutritional content and reduction of food waste better than any other method . its greatest asset is its affordability, invariably offering consumers value for money.

(Olokor et al., 2007). The quality of frozen fish is controlled by many factors, among which are the type of protective packaging used, maintenance of proper storage temperature and freezing properties of different species (Beroum and and Jooyandeh, 2010). The complexity of the marketing and distribution of frozen fish, coupled with erratic power supply in Nigeria that makes it impossible to maintain constant freezing temperature and at $38^{\circ} \mathrm{C}\left(100^{\circ} \mathrm{F}\right)$ ambient temperature of the tropics makes fish quality deteriorates very rapidly. The most important changes are oxidation of lipids resulting in rancid odour and flavour, toughening due to protein denaturation and aggregation, discolouration largely due to oxidation reaction and freezer burn due to constant defrosting and pre-freezing process (Boonsupthip and Heldman, 2007). This has great impact on the nutritional value of fish and the health of consumers. Therefore, measurements of proximate profiles are often necessary to ensure stored fish products meet the requirements of food regulations and commercial specifications requirement (Tawfik, 2009). However, reports on the quality of imported frozen fish including blue whiting (Micromesistius poutassou) marketed in Nigeria are limited, therefore, this study is being undertaken to assess the quality of imported frozen blue whiting after a period of frozen storage in cold-rooms viz-a-viz the effect of different packaging material after purchase from the market on its nutrient composition and chemical properties within specified hours before consumption.

\section{MATERIALS AND METHODS}

Collection of samples: A total of eighty-four blue whiting (Micromesistius poutassou) were purchased and stored in a commercial cold room (Ekipec Cold Room at New Benin market, Benin City Edo State of Nigeria), during the period of the study. Three amples each replicated for unwrapped, Ziploc bag, foil paper and fish carton respectively were collected and taken to the laboratory in sealed container for analysis fortnightly between December, 2015 and March, 2016. The proximate and chemical analyses were carried out at Splendidstan Research Laboratory in Isihor, Benin City.

Proximate analysis: Proximate composition was determined according to the method of the Association of Official Analytical Chemists (AOAC,2005). This includes determination of crude protein, moisture, fat, ash, fibre and nitrogen free extract (NFE) content. The residue obtained from ether extracted was further treated with $1.25 \%$ hydrogen tetraoxosulphate (VI) acid and $1.25 \%$ of sodium hydroxide under heating for 30 minutes. The content was heated in a muffle furnace and reweighed to determine the ash content. The NFE content was determined by the use of Equation 1 by subtracting the percentage sum of protein, fat, moisture, fibre and ash content from $100 \%$.

Fish oil extraction process: The fish oil was extracted using soxhlet extractor at $69^{\circ} \mathrm{C}$ and n-hexane was used as the solvent. The fish sample was placed in a porous thimble covered with cotton wool and the solvent was heated to its boiling point for 1 hour and with further heating, evaporation and it was refluxing off the oil component into the flask intermittently every 2 mins. The separation of solvent from oil was carried out through the use of the rotary evaporator under reduced pressure of about $760 \mathrm{mmHgand}$ the extracted oil was collected and measured.

Determination of free fatty acids (FFA): The free fatty acids content of the oil was determined volumet- 
rically using aqueous sodium hydroxide $(0.1 \mathrm{M})$ and phenolphthalein indicator (1\% ethanol) according to American Oil Chemists' Society (AOAC,2005) method. A neutral mixture of diethyl ether: ethanol (1:1) $(50 \mathrm{ml})$ was used as a solvent. FFA-values were reported as $\%$ oleic acid by weight.

Determination of peroxide value (PV): The peroxide value was determined and expressed as meq $\mathrm{O}_{2} / \mathrm{kg}$ oil, according to AOCS (2011) method. Oil samples were dissolved in chloroform and mixed with glacial acetic acid (Sigma) and freshly prepared saturated potassium iodide solution. Liberated iodine was titrated with standard sodium thiosulphate $(0.01 \mathrm{M})$ solution using starch indicator (1\%).

Determination of the iodine value (IV): The iodine value was determined according to the A.O.A.C. (2005) method, using carbon tetrachloride as solvent. Dissolved oil sample was mixed with $25.0 \mathrm{ml}$ of Hanus reagent (iodine monobromide) and $20 \mathrm{ml}$ of freshly prepared potassium iodide $(10 \%)$ solution. Liberated iodine was titrated with standard sodium thiosulphate $(0.1 \mathrm{M})$ solution, using carbon tetrachloride as a blank and starch as an indicator.

Determination of acid value (AV): Acid value was determined according to AOCS (2011). Acid value was analyzed by titration of approximately $1 \mathrm{~g}$ of fat, dissolved in approximately $50 \mathrm{ml}$ neutralized isopropanol, with standardized $0.1 \mathrm{~N}$ or $0.5 \mathrm{~N}$ potassium hydroxide; using phenolphthalein as indicator with constant shaking until a pink colour (end point) was observed and the value recorded.

Saponification value (SV): $2.00 \mathrm{~g}$ of the sample was weighed into a flask and $50 \mathrm{ml}$ alcoholic potassium hydroxide was pipetted into the flask. This was then attached to a reflux condenser; the mixture was allowed to boil for 2 hours with constant shaking. At the end of the refluxing period, the flask was cooled to $60^{\circ}$ $\mathrm{C}$ and rinsed with $10 \mathrm{ml}$ distilled water. Thereafter, few drops of phenolphthalein was added to the warm solution before being titrated against $1.0 \mathrm{~N}$ hydrogen tetraoxosulphate (VI) acid and the indicator pink colour disappeared. Same procedure was used for the other samples and the blank solution.

Hydroxyl value (HV): The fat sample was dissolved in acetic anhydride - pyridine reagent ( $\mathrm{N}$-acetyl-1,2dihydro-2-pyridylactic acid), placed in the $95-100^{\circ} \mathrm{C}$ oil bath and shake vigorously until all the solid material was melted and thoroughly mixed into the solution. It was removed and allowed to cool in a desicator, 10 $\mathrm{ml}$ of water was added and it was returned to the oil bath to complete the hydrolysis of the excess acetic anhydride $\left(\mathrm{CH}_{3} \mathrm{CO}\right)_{2} \mathrm{O}$ reagent, after which it was allowed to cool. $25 \mathrm{ml}$ neutralized alcohol was added and the resulting solution was titrated with methanolic potassium hydroxide,using $1 \mathrm{ml}$ of phenolphthalein indicator with constant shaking until a faint pink colouration was observed and the value recorded.
Statistical analysis: The data were arranged in a completely randomized design (CRD) with three (3) replications. Data collected were subjected to statistical analysis using one-way analysis of variance test at $p<$ 0.05 level of significance and means were separated using the Duncan Multiple Range Test at 5\% level of significance. The software used for the analysis is statistical package for social science (SPSS version 21).

\section{RESULTS}

The mean range of moisture content at different time of the day was $58.84 \pm 1.82-65.29 \pm 3.99 \%$, the highest value occurred in samples wrapped in Ziploc bag at the $4^{\text {th }}$ hour and lowest value occurred in samples wrapped with fish carton at the initial hour of analysis as shown in Table 1. Similarly, the mean moisture content increased with increasing storage period with the highest value of $69.41 \pm 1.70 \%$ in samples packed in Ziploc bag in the $12^{\text {th }}$ week and lowest value of $55.98 \pm 0.57 \%$ in samples wrapped in foil paper at the initial (0) week of the study as shown in Table 2. For all the packaging materials, samples packed in Ziploc bag had the highest mean moisture content of $64.93 \pm 3.83 \%$ and samples wrapped in carton had the lowest mean moisture content of $59.28 \pm 1.67 \%$ during the period of study (Table 3). Analysis of variance (ANOVA) showed that there was no significant difference $(p>0.05)$ in means between the different time of analysis during the hour of analysis after removal from storage but significant difference $(\mathrm{p}<0.05)$ was observed between the packaging materials as well as between the storage periods, but further separation of means using Duncan Multiple Range Test (DMRT) revealed that there was no significant difference $(p>0.05)$ between samples wrapped in foil paper and unwrapped samples during the study period as shown in Table 3. Pearson's correlation showed that there was a strong negative correlation ( $\mathrm{r}$ $=-0.957$ ) between moisture and protein for all the packaging materials.

The mean protein content at different time of the day using different packaging materials ranged between $24.35 \pm 0.60-26.98 \pm 0.61 \%$ during the study with the highest value in samples wrapped in carton analyzed at the initial time and lowest value in samples packed in Ziploc bag at the $4^{\text {th }}$ hour of analysis as shown in Table 1. The highest mean protein content of $27.76 \pm 0.23 \%$ was observed in the samples wrapped in carton at the initial (0) week of the study while the lowest value of $23.64 \pm 0.13 \%$ was observed in the $12^{\text {th }}$ week in samples packed in Ziploc bag as shown in Table 2. Therefore, samples wrapped in carton had the highest mean protein content of $26.86 \pm 0.55 \%$ and samples packed in Ziploc bag had the lowest mean protein content of $24.48 \pm 0.65 \%$ during the period of study (Table 3 ). ANOVA indicated that there was no significant difference $(p>0.05)$ in mean protein content between the different time of the day but significant difference 
A. E. Odiko and E. Joseph / J. Appl. \& Nat. Sci. 9 (3): 1881 - 1893 (2017)

Table 1. Mean proximate composition (\%) of frozen Micromesistius poutassou at different hour of the sampling day from December, 2015 to March, 2016.

\begin{tabular}{|c|c|c|c|c|}
\hline \multirow[b]{2}{*}{ Sample } & \multicolumn{3}{|c|}{ Sampling time (Hours) } & \multirow[b]{2}{*}{$4(\mathrm{hr})$} \\
\hline & Parameter & Initial (0hr) & 2(hr) & \\
\hline \multirow[t]{6}{*}{ Unwrapped } & Moisture & $60.05 \pm 1.95^{\mathrm{a}}$ & $60.36 \pm 1.88^{\mathrm{a}}$ & $60.62 \pm 1.84^{\mathrm{a}}$ \\
\hline & Protein & $25.00 \pm 0.69^{\mathrm{a}}$ & $24.93 \pm 0.66^{\mathrm{a}}$ & $24.89 \pm 0.65^{\mathrm{a}}$ \\
\hline & Ash & $0.61 \pm 0.04^{\mathrm{a}}$ & $0.60 \pm 0.04^{\mathrm{a}}$ & $0.59 \pm 0.04^{\mathrm{a}}$ \\
\hline & Fibre & $0.39 \pm 0.13^{\mathrm{a}}$ & $0.35 \pm 0.12^{\mathrm{a}}$ & $0.32 \pm 0.12^{\mathrm{a}}$ \\
\hline & Fat & $12.70 \pm 0.48^{\mathrm{a}}$ & $12.57 \pm 0.47^{\mathrm{a}}$ & $12.45 \pm 0.47^{\mathrm{a}}$ \\
\hline & Carbohydrate & $1.25 \pm 0.74^{\mathrm{a}}$ & $1.19 \pm 0.71^{\mathrm{a}}$ & $1.14 \pm 0.70^{\mathrm{a}}$ \\
\hline \multirow[t]{6}{*}{ Ziploc } & Moisture & $62.85 \pm 3.09^{\mathrm{a}}$ & $64.44 \pm 4.10^{\mathrm{a}}$ & $65.29 \pm 3.99^{\mathrm{a}}$ \\
\hline & Protein & $24.60 \pm 0.69^{\mathrm{a}}$ & $24.47 \pm 0.65^{\mathrm{a}}$ & $24.35 \pm 0.60^{\mathrm{a}}$ \\
\hline & Ash & $0.40 \pm 0.08^{\mathrm{a}}$ & $0.38 \pm 0.08^{\mathrm{a}}$ & $0.36 \pm 0.08^{\mathrm{a}}$ \\
\hline & Fibre & $0.41 \pm 0.12^{\mathrm{a}}$ & $0.37 \pm 0.11^{\mathrm{a}}$ & $0.34 \pm \mathrm{O} .11^{\mathrm{a}}$ \\
\hline & Fat & $10.71 \pm 1.58^{\mathrm{b}}$ & $9.45 \pm 2.73^{\mathrm{ab}}$ & $8.89 \pm 2.67^{\mathrm{a}}$ \\
\hline & Carbohydrate & $1.02 \pm 0.68^{\mathrm{a}}$ & $0.89 \pm 0.63^{\mathrm{a}}$ & $0.77 \pm 0.58^{\mathrm{a}}$ \\
\hline \multirow[t]{6}{*}{ Foil } & Moisture & $59.70 \pm 3.24^{\mathrm{a}}$ & $61.10 \pm 3.73^{\mathrm{a}}$ & $62.00 \pm 3.64^{\mathrm{a}}$ \\
\hline & Protein & $25.87 \pm 0.77^{\mathrm{a}}$ & $25.75 \pm 0.76^{\mathrm{a}}$ & $25.57 \pm 0.74^{\mathrm{a}}$ \\
\hline & Ash & $0.39 \pm 0.09^{\mathrm{a}}$ & $0.36 \pm 0.08^{\mathrm{a}}$ & $0.34 \pm 0.08^{\mathrm{a}}$ \\
\hline & Fibre & $0.48 \pm 0.12^{\mathrm{a}}$ & $0.45 \pm 0.11^{\mathrm{a}}$ & $0.42 \pm 0.11^{\mathrm{a}}$ \\
\hline & Fat & $12.25 \pm 1.64^{\mathrm{a}}$ & $11.16 \pm 2.17^{\mathrm{a}}$ & $10.67 \pm 2.15^{\mathrm{a}}$ \\
\hline & Carbohydrate & $1.30 \pm 0.75^{\mathrm{a}}$ & $1.52 \pm 1.51^{\mathrm{a}}$ & $1.00 \pm 0.72^{\mathrm{a}}$ \\
\hline \multirow[t]{6}{*}{ Fish Carton } & Moisture & $58.84 \pm 1.82^{\mathrm{a}}$ & $59.33 \pm 1.61^{\mathrm{a}}$ & $59.66 \pm 1.54^{\mathrm{a}}$ \\
\hline & Protein & $26.98 \pm 0.61^{\mathrm{a}}$ & $26.85 \pm 0.54^{\mathrm{a}}$ & $26.76 \pm 0.51^{\mathrm{a}}$ \\
\hline & Ash & $0.47 \pm 0.04^{\mathrm{a}}$ & $0.46 \pm 0.04^{\mathrm{a}}$ & $0.45 \pm 0.03^{\mathrm{a}}$ \\
\hline & Fibre & $0.31 \pm 0.06^{\mathrm{a}}$ & $0.29 \pm 0.06^{\mathrm{a}}$ & $0.28 \pm 0.06^{\mathrm{a}}$ \\
\hline & Fat & $12.31 \pm 0.56^{\mathrm{a}}$ & $12.10 \pm 0.51^{\mathrm{a}}$ & $11.98 \pm 0.50^{\mathrm{a}}$ \\
\hline & Carbohydrate & $1.09 \pm 0.65^{\mathrm{a}}$ & $0.96 \pm 0.57^{\mathrm{a}}$ & $0.87 \pm 0.54^{\mathrm{a}}$ \\
\hline
\end{tabular}

Different superscript within the same row indicates significant difference $(\mathrm{p}<0.05)$ in means.

$(p<0.05)$ was observed between storage periods as well as packaging materials. Further separation of means using DMRT showed that there was no significant difference $(\mathrm{p}>0.05)$ between the $10^{\text {th }}$ and $12^{\text {th }}$ week for the different packaging materials during the period of study. Pearson's correlation showed that there was a strong positive correlation $(\mathrm{r}=0.731)$ between protein and fat for unwrapped fish samples. Similarly, there was also strong positive correlation between protein and fat for all the packaging materials.

The mean range of fat content at different time of the day was $8.89 \pm 2.67-12.70 \pm 0.48$ with the highest value occurring at the initial hour for unwrapped samples and lowest value occurring in the $4^{\text {th }}$ hour for samples packed in Ziploc bag as shown in Table 1. The mean fat content during the study period ranged between $6.36 \pm 1.62-14.17 \pm 0.22$; the highest value was observed at the initial (0) week of the study in samples wrapped in foil paper and the lowest value was obtained in the $12^{\text {th }}$ week in samples packed in Ziploc bag as shown in Table 2. During the period of study, the highest mean fat content of $12.57 \pm 0.48$ was observed in unwrapped samples while the lowest mean fat content of $9.68 \pm 2.47$ was recorded in samples packed in Ziploc bag (Table 3). Analysis of variance showed that there was no significant difference $(p>0.05)$ in mean fat content between the different time of the day for the different packaging materials except for samples packed in Ziploc bag, but there was a significant difference $(p<0.05)$ between the storage periods for the different packaging materials. Further analysis using DMRT showed that some level of significant difference $(\mathrm{p}<0.05)$ were observed in mean fat content between the storage periods for the different packaging materials (Table 2 ).

The mean ash content at different time of the day was highest $(0.61 \pm 0.04)$ at the initial time in the unwrapped samples and lowest $(0.34 \pm 0.08)$ at the $4^{\text {th }}$ hour in samples wrapped in foil paper as shown in Table 1. Ash content ranged between $0.27 \pm 0.04-0.67 \pm 0.02$ during the period of study with the highest value at the initial (0) week of the study in the unwrapped samples at the initial hour and lowest value in the $12^{\text {th }}$ week in samples wrapped in foil paper as shown in Table 2. For all the packaging materials the highest ash content was obtained in samples wrapped in carton and the lowest was recorded in samples wrapped in foil paper as shown in Table 3. ANOVA showed that there was significant differences $(\mathrm{p}<0.05)$ in mean ash content between the different packaging materials as well as between the storage periods, but there was no significant difference $(p>0.05)$ in mean ash content between the different times of analysis (Table 1). DMRT showed that there was significant difference $(p<0.05)$ 
A. E. Odiko and E. Joseph / J. Appl. \& Nat. Sci. 9 (3): 1881 - 1893 (2017)

Table 2. Mean proximate composition of frozen blue whiting during the period of study from December, 2015 to March, 2016.

\begin{tabular}{|c|c|c|c|c|c|c|c|c|}
\hline \multirow[b]{2}{*}{ Sample } & \multirow[b]{2}{*}{ Parameter } & \multicolumn{7}{|c|}{ Storage period (Weeks) } \\
\hline & & Initial (0wk) & $2(w k)$ & 4(wk) & $6(w k)$ & $8(w k)$ & $10(w k)$ & $12(w k)$ \\
\hline \multirow[t]{6}{*}{ Unwrapped } & Moisture & $57.72 \pm 0.60^{\mathrm{a}}$ & $59.10 \pm 0.51^{b}$ & $59.52 \pm 0.49^{\mathrm{bc}}$ & $59.87 \pm 0.47^{\mathrm{C}}$ & $60.28 \pm 0.45^{\mathrm{d}}$ & $62.75 \pm 0.24^{\mathrm{e}}$ & $63.15 \pm 0.24^{\mathrm{e}}$ \\
\hline & Protein & $25.61 \pm 0.27^{\mathrm{c}}$ & $25.32 \pm 0.29^{\mathrm{b}}$ & $25.29 \pm 0.29^{b}$ & $25.20 \pm 0.27^{\mathrm{b}}$ & $25.17 \pm 0.27^{\mathrm{b}}$ & $24.00 \pm 0.05^{\mathrm{a}}$ & $23.97 \pm 0.05^{\mathrm{a}}$ \\
\hline & Ash & $0.67 \pm 0.02^{\mathrm{d}}$ & $0.63 \pm 0.02^{\mathrm{c}}$ & $0.62 \pm 0.02^{\mathrm{c}}$ & $0.59 \pm 0.02^{\mathrm{b}}$ & $0.59 \pm 0.02^{\mathrm{b}}$ & $0.56 \pm 0.01^{\mathrm{a}}$ & $0.55 \pm 0.01^{\mathrm{a}}$ \\
\hline & Fibre & $0.56 \pm 0.05^{\mathrm{d}}$ & $0.42 \pm 0.06^{\mathrm{c}}$ & $0.40 \pm 0.06^{\mathrm{c}}$ & $0.32 \pm 0.07^{\mathrm{b}}$ & $0.30 \pm 0.06^{\mathrm{b}}$ & $0.24 \pm 0.07^{\mathrm{a}}$ & $0.22 \pm 0.07^{\mathrm{a}}$ \\
\hline & Fat & $13.43 \pm 0.13^{\mathrm{d}}$ & $12.81 \pm 0.16^{\mathrm{c}}$ & $12.80 \pm 0.16^{\mathrm{c}}$ & $12.43 \pm 0.16^{\mathrm{b}}$ & $12.42 \pm 0.16^{\mathrm{b}}$ & $12.06 \pm 0.15^{\mathrm{a}}$ & $12.05 \pm 0.15^{\mathrm{a}}$ \\
\hline & Carbohydrate & $2.00 \pm 0.29^{\mathrm{f}}$ & $1.71 \pm 0.30^{\mathrm{f}}$ & $1.59 \pm 0.29^{\mathrm{e}}$ & $1.36 \pm 0.29^{\mathrm{d}}$ & $1.24 \pm 0.27^{\mathrm{c}}$ & $0.39 \pm 0.05^{\mathrm{b}}$ & $0.04 \pm 0.04^{\mathrm{a}}$ \\
\hline \multirow[t]{6}{*}{ Ziploc } & Moisture & $59.40 \pm 0.43^{\mathrm{a}}$ & $61.42 \pm 0.91^{\mathrm{b}}$ & $61.52 \pm 0.90^{\mathrm{b}}$ & $64.09 \pm 1.23^{\mathrm{c}}$ & $64.18 \pm 1.23^{\mathrm{c}}$ & $69.34 \pm 1.71^{\mathrm{d}}$ & $69.41 \pm 1.70^{\mathrm{d}}$ \\
\hline & Protein & $25.40 \pm 0.18^{\mathrm{d}}$ & $24.93 \pm 0.24^{\mathrm{c}}$ & $24.90 \pm 0.24^{\mathrm{c}}$ & $24.42 \pm 0.26^{\mathrm{b}}$ & $24.39 \pm 0.26^{\mathrm{b}}$ & $23.67 \pm 0.12^{\mathrm{a}}$ & $23.64 \pm 0.13^{\mathrm{a}}$ \\
\hline & Ash & $0.50 \pm 0.02^{\mathrm{d}}$ & $0.44 \pm 0.03^{\mathrm{c}}$ & $0.43 \pm 0.03^{\mathrm{c}}$ & $0.36 \pm 0.04^{\mathrm{b}}$ & $0.35 \pm 0.04^{\mathrm{b}}$ & $0.30 \pm 0.05^{\mathrm{a}}$ & $0.29 \pm 0.05^{\mathrm{a}}$ \\
\hline & Fibre & $0.57 \pm 0.03^{\mathrm{d}}$ & $0.45 \pm 0.04^{\mathrm{c}}$ & $0.43 \pm 0.04^{\mathrm{c}}$ & $0.34 \pm 0.05^{\mathrm{b}}$ & $0.33 \pm 0.06^{\mathrm{b}}$ & $0.26 \pm 0.06^{\mathrm{a}}$ & $0.25 \pm 0.06^{\mathrm{a}}$ \\
\hline & Fat & $12.33 \pm 0.11^{\mathrm{c}}$ & $11.42 \pm 0.51^{\mathrm{c}}$ & $11.41 \pm 0.51^{\mathrm{c}}$ & $9.96 \pm 0.96^{\mathrm{b}}$ & $9.95 \pm 0.96^{\mathrm{b}}$ & $6.36 \pm 1.62^{\mathrm{a}}$ & $6.36 \pm 1.62^{\mathrm{a}}$ \\
\hline & Carbohydrate & $1.81 \pm 0.14^{\mathrm{d}}$ & $1.34 \pm 0.18^{\mathrm{c}}$ & $1.31 \pm 0.18^{\mathrm{c}}$ & $0.83 \pm 0.19^{b}$ & $0.83 \pm 0.20^{\mathrm{b}}$ & $0.08 \pm 0.04^{\mathrm{a}}$ & $0.05 \pm 0.04^{\mathrm{a}}$ \\
\hline \multirow[t]{6}{*}{ Foil } & Moisture & $55.98 \pm 0.57^{\mathrm{a}}$ & $58.53 \pm 1.19^{b}$ & $58.77 \pm 1.18^{\mathrm{b}}$ & $60.80 \pm 1.25^{\mathrm{c}}$ & $61.04 \pm 1.24^{\mathrm{c}}$ & $65.65 \pm 1.52^{\mathrm{d}}$ & $65.77 \pm 1.46^{\mathrm{d}}$ \\
\hline & Protein & $26.61 \pm 0.31^{\mathrm{d}}$ & $26.22 \pm 0.36^{\mathrm{c}}$ & $26.19 \pm 0.36^{\mathrm{c}}$ & $25.83 \pm 0.38^{\mathrm{b}}$ & $25.80 \pm 0.38^{\mathrm{b}}$ & $24.72 \pm 0.28^{\mathrm{a}}$ & $24.74 \pm 0.25^{\mathrm{a}}$ \\
\hline & Ash & $0.49 \pm 0.03^{\mathrm{d}}$ & $0.42 \pm 0.03^{\mathrm{c}}$ & $0.42 \pm 0.03^{\mathrm{c}}$ & $0.34 \pm 0.04^{\mathrm{b}}$ & $0.34 \pm 0.03^{\mathrm{b}}$ & $0.28 \pm 0.06^{\mathrm{a}}$ & $0.27 \pm 0.04^{\mathrm{a}}$ \\
\hline & Fibre & $0.65 \pm 0.04^{\mathrm{d}}$ & $0.52 \pm 0.04^{\mathrm{c}}$ & $0.51 \pm 0.04^{\mathrm{c}}$ & $0.42 \pm 0.05^{\mathrm{b}}$ & $0.40 \pm 0.05^{\mathrm{b}}$ & $0.34 \pm 0.06^{\mathrm{a}}$ & $0.32 \pm 0.05^{\mathrm{a}}$ \\
\hline & Fat & $14.17 \pm 0.22^{\mathrm{d}}$ & $12.59 \pm 0.87^{\mathrm{c}}$ & $12.57 \pm 0.87^{\mathrm{c}}$ & $11.29 \pm 0.83^{\mathrm{b}}$ & $11.28 \pm 0.83^{\mathrm{b}}$ & $8.81 \pm 1.35^{\mathrm{a}}$ & $8.80 \pm 1.34^{\mathrm{a}}$ \\
\hline & Carbohydrate & $2.11 \pm 0.23^{\mathrm{e}}$ & $1.72 \pm 0.25^{\mathrm{d}}$ & $1.53 \pm 0.20^{\mathrm{cd}}$ & $1.32 \pm 0.30^{\mathrm{c}}$ & $1.14 \pm 0.26^{\mathrm{b}}$ & $1.01 \pm 2.37^{\mathrm{b}}$ & $0.08 \pm 0.10^{\mathrm{a}}$ \\
\hline \multirow[t]{6}{*}{ Fish Carton } & Moisture & $56.36 \pm 0.66^{\mathrm{a}}$ & $58.44 \pm 0.63^{b}$ & $58.76 \pm 0.64^{\mathrm{b}}$ & $59.30 \pm 0.32^{\mathrm{c}}$ & $59.62 \pm 0.39^{\mathrm{c}}$ & $61.11 \pm 0.42^{\mathrm{d}}$ & $61.37 \pm 0.63^{\mathrm{d}}$ \\
\hline & Protein & $27.76 \pm 0.23^{\mathrm{c}}$ & $27.06 \pm 0.19^{b}$ & $27.03 \pm 0.19^{b}$ & $26.90 \pm 0.15^{\mathrm{b}}$ & $26.87 \pm 0.15^{\mathrm{b}}$ & $26.20 \pm 0.35^{\mathrm{a}}$ & $26.20 \pm 0.31^{\mathrm{a}}$ \\
\hline & Ash & $0.51 \pm 0.02^{\mathrm{d}}$ & $0.48 \pm 0.02^{\mathrm{c}}$ & $0.47 \pm 0.02^{\mathrm{c}}$ & $0.45 \pm 0.02^{\mathrm{b}}$ & $0.45 \pm 0.02^{\mathrm{b}}$ & $0.43 \pm 0.02^{\mathrm{a}}$ & $0.42 \pm 0.02^{\mathrm{a}}$ \\
\hline & Fibre & $0.38 \pm 0.02^{\mathrm{d}}$ & $0.32 \pm 0.02^{\mathrm{c}}$ & $0.31 \pm 0.02^{\mathrm{c}}$ & $0.28 \pm 0.03^{\mathrm{b}}$ & $0.27 \pm 0.04^{\mathrm{b}}$ & $0.25 \pm 0.05^{\mathrm{a}}$ & $0.24 \pm 0.05^{\mathrm{a}}$ \\
\hline & Fat & $13.00 \pm 0.13^{\mathrm{d}}$ & $12.42 \pm 0.31^{\mathrm{c}}$ & $12.41 \pm 0.31^{\mathrm{c}}$ & $11.95 \pm 0.24^{\mathrm{b}}$ & $11.94 \pm 0.24^{\mathrm{b}}$ & $11.60 \pm 0.23^{\mathrm{a}}$ & $11.59 \pm 0.23^{\mathrm{a}}$ \\
\hline & Carbohydrate & $1.98 \pm 0.34^{\mathrm{f}}$ & $1.28 \pm 0.24^{\mathrm{e}}$ & $1.01 \pm 0.19^{\mathrm{cd}}$ & $1.11 \pm 0.16^{\mathrm{d}}$ & $0.85 \pm 0.14^{\mathrm{c}}$ & $0.42 \pm 0.06^{\mathrm{b}}$ & $0.18 \pm 0.28^{\mathrm{a}}$ \\
\hline
\end{tabular}

Different superscript within the same row indicates significant difference $(\mathrm{p}<0.05)$ in means.

Table 3: Mean proximate composition for the different packaging materials.

\begin{tabular}{lllll}
\hline & \multicolumn{3}{c}{ Packaging material } \\
\cline { 2 - 4 } Parameter & Unwrapped & Ziploc & Foil & Fish Carton \\
\hline Moisture (\%) & $60.34 \pm 1.88^{\mathrm{b}}$ & $64.19 \pm 3.83^{\mathrm{c}}$ & $60.93 \pm 3.62^{\mathrm{b}}$ & $59.28 \pm 1.67^{\mathrm{a}}$ \\
Protein (\%) & $24.94 \pm 0.66^{\mathrm{a}}$ & $24.48 \pm 0.65^{\mathrm{a}}$ & $25.73 \pm 0.76^{\mathrm{b}}$ & $26.86 \pm 0.55^{\mathrm{c}}$ \\
Ash (\%) & $0.60 \pm 0.04^{\mathrm{c}}$ & $0.38 \pm 0.08^{\mathrm{a}}$ & $0.37 \pm 0.08^{\mathrm{a}}$ & $0.46 \pm 0.04^{\mathrm{b}}$ \\
Fibre (\%) & $0.35 \pm 0.13^{\mathrm{b}}$ & $0.37 \pm 0.12^{\mathrm{b}}$ & $0.45 \pm 0.12^{\mathrm{c}}$ & $0.29 \pm 0.06^{\mathrm{a}}$ \\
Fats (\%) & $12.57 \pm 0.48^{\mathrm{c}}$ & $9.68 \pm 2.47^{\mathrm{a}}$ & $11.36 \pm 2.08^{\mathrm{b}}$ & $12.13 \pm 0.53^{\mathrm{c}}$ \\
Carbohydrate (\%) & $1.19 \pm 0.71^{\mathrm{c}}$ & $0.89 \pm 0.63^{\mathrm{a}}$ & $1.27 \pm 1.06^{\mathrm{c}}$ & $0.97 \pm 0.59^{\mathrm{b}}$ \\
\hline
\end{tabular}

Different superscript within the same row indicates significant difference $(\mathrm{p}<0.05)$ in means.

in mean between the different packaging materials except for samples wrapped in foil paper and Ziploc. Similarly, DMRT showed that there was no significant difference $(\mathrm{p}>0.05)$ between the $2^{\text {nd }}$ and $4^{\text {th }}$ week; $6^{\text {th }}$ and $8^{\text {th }}$ week as well as $10^{\text {th }}$ and $12^{\text {th }}$ week for the different packaging materials throughout the study (Table 2 ). For all the packaging materials ash and moisture content showed strong negative correlation $(\mathrm{r}=$ 0.873 ) which was significant at 0.01 level of probability as indicated by the use of Pearson's correlation.

The mean fibre content at the different time of the day ranged between $0.28 \pm 0.06-0.48 \pm 0.12$ with the highest value in the initial hour of analysis in samples wrapped in foil paper and lowest value in the $4^{\text {th }}$ hour in samples wrapped in fish carton as shown in Table 1. The mean fibre content during the study had the highest value of $0.65 \pm 0.04$ at the initial $(0)$ week of the study in samples wrapped in foil paper and lowest value of $0.22 \pm 0.07$ in the $12^{\text {th }}$ week in the unwrapped samples as shown in Table 2. ANOVA revealed that there was no significant difference $(\mathrm{p}>0.05)$ in mean fibre content between the different time of analysis during the day for the different packaging materials during the period of study (Table 1). ANOVA indicated significant differences $(p<0.05)$ in the fibre content between the different packaging materials and between the stor- 
A. E. Odiko and E. Joseph / J. Appl. \& Nat. Sci. 9 (3): 1881 - 1893 (2017)

Table 4. Mean chemical properties of frozen blue whiting at different time of the day during the period of study (December, 2015 to March, 2016).

\begin{tabular}{|c|c|c|c|c|}
\hline \multirow[b]{2}{*}{ Sample } & \multirow[b]{2}{*}{ Parameter } & \multicolumn{3}{|c|}{ Time (hour) } \\
\hline & & Initial (0hr) & $2(\mathrm{hr})$ & $4(\mathrm{hr})$ \\
\hline \multirow[t]{6}{*}{ Unwrapped } & IV & $40.43 \pm 38.88^{b}$ & $33.68 \pm 32.31^{\mathrm{a}}$ & $30.68 \pm 31.38^{\mathrm{a}}$ \\
\hline & SV & $335.81 \pm 96.88^{\mathrm{a}}$ & $333.25 \pm 81.14^{\mathrm{a}}$ & $332.01 \pm 89.31^{\mathrm{a}}$ \\
\hline & PV & $12.77 \pm 13.80^{\mathrm{a}}$ & $24.64 \pm 20.69^{\mathrm{b}}$ & $28.72 \pm 24.62^{\mathrm{c}}$ \\
\hline & FFA & $18.09 \pm 18.62^{\mathrm{a}}$ & $23.44 \pm 20.94^{\mathrm{b}}$ & $28.89 \pm 27.21^{\mathrm{c}}$ \\
\hline & $\mathrm{AV}$ & $26.40 \pm 23.49^{\mathrm{a}}$ & $31.41 \pm 28.88^{\mathrm{b}}$ & $35.11 \pm 33.12^{\mathrm{c}}$ \\
\hline & $\mathrm{HV}$ & $28.85 \pm 23.49^{\mathrm{a}}$ & $33.70 \pm 29.03^{b}$ & $37.37 \pm 33.30^{\mathrm{c}}$ \\
\hline \multirow[t]{6}{*}{ Ziploc } & IV & $52.08 \pm 41.33^{\mathrm{c}}$ & $40.64 \pm 35.35^{\mathrm{b}}$ & $35.07 \pm 33.31^{\mathrm{a}}$ \\
\hline & SV & $289.30 \pm 82.46^{\mathrm{a}}$ & $363.17 \pm 113.60^{\mathrm{b}}$ & $383.71 \pm 116.77^{b}$ \\
\hline & PV & $15.80 \pm 19.73^{\mathrm{a}}$ & $30.40 \pm 29.53^{\mathrm{ab}}$ & $38.24 \pm 34.46^{\mathrm{b}}$ \\
\hline & FFA & $20.17 \pm 22.30^{\mathrm{b}}$ & $26.78 \pm 27.12^{\mathrm{b}}$ & $34.67 \pm 34.99^{\mathrm{a}}$ \\
\hline & $\mathrm{AV}$ & $31.23 \pm 28.13^{\mathrm{b}}$ & $36.68 \pm 34.87^{\mathrm{b}}$ & $41.47 \pm 39.91^{\mathrm{a}}$ \\
\hline & $\mathrm{HV}$ & $33.68 \pm 28.13^{\mathrm{b}}$ & $38.98 \pm 35.02^{\mathrm{b}}$ & $43.73 \pm 40.09^{\mathrm{a}}$ \\
\hline \multirow[t]{6}{*}{ Foil } & IV & $27.46 \pm 30.74^{\mathrm{b}}$ & $23.26 \pm 27.24^{\mathrm{a}}$ & $21.33 \pm 25.45^{\mathrm{a}}$ \\
\hline & SV & $414.87 \pm 141.75^{\mathrm{b}}$ & $411.09 \pm 124.32^{\mathrm{b}}$ & $409.24 \pm 132.79^{\mathrm{a}}$ \\
\hline & PV & $16.13 \pm 17.60^{\mathrm{a}}$ & $31.13 \pm 26.45^{\mathrm{b}}$ & $36.25 \pm 31.51^{\mathrm{c}}$ \\
\hline & FFA & $22.85 \pm 23.76^{\mathrm{a}}$ & $29.60 \pm 26.77^{\mathrm{a}}$ & $36.37 \pm 34.84^{\mathrm{b}}$ \\
\hline & $\mathrm{AV}$ & $33.24 \pm 30.11^{\mathrm{a}}$ & $39.56 \pm 37.00^{\mathrm{a}}$ & $44.16 \pm 42.46^{\mathrm{b}}$ \\
\hline & $\mathrm{HV}$ & $35.69 \pm 30.11^{\mathrm{a}}$ & $42.01 \pm 37.00^{\mathrm{b}}$ & $46.61 \pm 42.46^{\mathrm{b}}$ \\
\hline \multirow[t]{6}{*}{ Carton } & IV & $57.30 \pm 43.75^{\mathrm{c}}$ & $45.99 \pm 38.74^{b}$ & $41.70 \pm 36.92^{\mathrm{a}}$ \\
\hline & SV & $285.00 \pm 79.27^{\mathrm{a}}$ & $353.78 \pm 111.25^{\mathrm{b}}$ & $372.91 \pm 112.27^{b}$ \\
\hline & PV & $16.91 \pm 21.11^{\mathrm{a}}$ & $31.59 \pm 31.70^{\mathrm{ab}}$ & $39.12 \pm 37.35^{\mathrm{b}}$ \\
\hline & FFA & $29.69 \pm 32.87^{\mathrm{a}}$ & $34.68 \pm 38.74^{\mathrm{b}}$ & $44.12 \pm 50.33^{\mathrm{c}}$ \\
\hline & $\mathrm{AV}$ & $32.28 \pm 28.87^{\mathrm{a}}$ & $37.16 \pm 36.35^{\mathrm{ab}}$ & $43.05 \pm 41.23^{\mathrm{b}}$ \\
\hline & $\mathrm{HV}$ & $34.73 \pm 28.87^{\mathrm{a}}$ & $39.45 \pm 36.50^{b}$ & $45.31 \pm 41.41^{\mathrm{c}}$ \\
\hline
\end{tabular}

Different superscript within the same row indicates significant difference $(\mathrm{p}<0.05)$ in meansn: IV - Iodine Value, SV - Saponification Value, PV - Peroxide Value, FFA - Free Fatty Acid, AV - Acid Value and HV - Hydroxyl Value

age periods, but further separation of means using DMRT showed that there was no significant difference ( $p>0.05)$ in means between the $2^{\text {nd }}$ and $4^{\text {th }}$ week; $6^{\text {th }}$ and $8^{\text {th }}$ week; and $10^{\text {th }}$ and $12^{\text {th }}$ week of the study as shown in Table 2. Pearson's correlation analysis indicated that a strong negative correlation $(\mathrm{r}=-0.811)$ existed at 0.01 level of probability between fibre and moisture content for the different packaging materials. The mean NFE content ranged between $0.77 \pm 0.58$ $1.30 \pm 0.75$ at different time of the day with highest value in the initial time of analysis in samples wrapped in foil paper and lowest value in the $4^{\text {th }}$ hour of analysis in samples packed in Ziploc bag as shown in Table 1. The mean NFE content decreased with increasing storage time with highest value of $2.11 \pm 0.23$ at the initial (0) week of the study in samples wrapped in foil paper and lowest value of $0.04 \pm 0.04$ in the $12^{\text {th }}$ week in unwrapped samples as shown in Table 2.For all the packaging materials, samples wrapped in foil paper had the highest mean NFE content and the lowest NFE content was observed in samples packed in Ziploc bag as shown in Table 3. Although there were significant differences $(p<0.05)$ in mean NFE content between the different packaging materials and the storage periods as indicated by the use of ANOVA, further analysis using DMRT showed that there was no significant difference $(p>0.05)$ between unwrapped samples and samples wrapped in foil paper (Table 3 ).

Iodine had the highest mean value of $57.30 \pm 43.75 \mathrm{mg}$ $\mathrm{I}_{2} / 100 \mathrm{~g}$ oil in the initial hour of analysis in samples wrapped in fish carton and lowest value of $21.33 \pm 25.45 \mathrm{mg} \mathrm{I}_{2} / 100 \mathrm{~g}$ oil in the $4^{\text {th }}$ hour in samples wrapped in foil paper as shown in Table 4. High iodine value will make unsaturated fats molecules to become less stable and more susceptible to oxidation and rancidity, the mean range of iodine value during the period of study was $0.58 \pm 0.11-94.66 \pm 8.69 \mathrm{mg} \mathrm{I}_{2} / 100 \mathrm{~g}$ oil with the highest value at the initial (0) week of the study in unwrapped samples and lowest value in the $12^{\text {th }}$ week in samples wrapped in foil paper as shown in Table 5. For all the different packaging materials, the highest iodine value was obtained in samples 
Table 5. Mean chemical properties of frozen blue whiting at different weeks during the period of study (December, 2015 to March, 2016).

\begin{tabular}{|c|c|c|c|c|c|c|c|c|}
\hline & \multicolumn{7}{|c|}{ Storage period (Week) } \\
\hline & & Fresh(0wk) & $2(w k)$ & $4(w k)$ & $6(w k)$ & $8(w k)$ & $10(w k)$ & $12(w k)$ \\
\hline \multirow[t]{6}{*}{$\mathrm{U}$} & IV & $94.66 \pm 8.69^{\mathrm{a}}$ & $63.77 \pm 18.26^{b}$ & $42.50 \pm 6.80^{\mathrm{c}}$ & $33.80 \pm 9.43^{\mathrm{d}}$ & $7.39 \pm 3.53^{\mathrm{e}}$ & $1.40 \pm 0.62^{\mathrm{e}}$ & $1.02 \pm 0.20^{\mathrm{e}}$ \\
\hline & SP & $210.97 \pm 6.84^{\mathrm{a}}$ & $245.96 \pm 6.63^{b}$ & $283.82 \pm 25.32^{\mathrm{c}}$ & $324.75 \pm 7.80^{\mathrm{d}}$ & $393.29 \pm 8.49^{\mathrm{e}}$ & $418.80 \pm 8.20^{f}$ & $458.26 \pm 29.31^{\mathrm{g}}$ \\
\hline & PV & $2.77 \pm 1.10^{\mathrm{a}}$ & $4.85 \pm 2.12^{\mathrm{a}}$ & $7.19 \pm 2.50^{\mathrm{a}}$ & $16.88 \pm 7.31^{\mathrm{b}}$ & $23.28 \pm 10.55^{\mathrm{b}}$ & $42.70 \pm 14.78^{\mathrm{c}}$ & $56.63 \pm 13.10^{\mathrm{d}}$ \\
\hline & FFA & $3.48 \pm 1.61^{\mathrm{a}}$ & $8.05 \pm 3.12^{\mathrm{ab}}$ & $8.08 \pm 2.16^{\mathrm{ab}}$ & $14.68 \pm 2.99^{\mathrm{bc}}$ & $17.94 \pm 5.30^{\mathrm{c}}$ & $48.38 \pm 8.39^{\mathrm{d}}$ & $63.68 \pm 14.83^{\mathrm{e}}$ \\
\hline & $\mathrm{AC}$ & $6.11 \pm 1.21^{\mathrm{a}}$ & $12.20 \pm 3.79^{\mathrm{ab}}$ & $11.98 \pm 2.38^{\mathrm{ab}}$ & $17.44 \pm 1.09^{b c}$ & $21.78 \pm 1.97^{\mathrm{c}}$ & $66.27 \pm 8.04^{\mathrm{d}}$ & $81.03 \pm 14.10^{\mathrm{e}}$ \\
\hline & HV & $7.75 \pm 0.96^{\mathrm{a}}$ & $14.65 \pm 3.79^{\mathrm{b}}$ & $14.43 \pm 2.38^{\mathrm{b}}$ & $19.89 \pm 1.09^{\mathrm{bc}}$ & $24.23 \pm 1.97^{\mathrm{c}}$ & $68.72 \pm 8.04^{\mathrm{d}}$ & $83.48 \pm 14.10^{\mathrm{e}}$ \\
\hline \multirow[t]{5}{*}{ Z } & IV & $90.01 \pm 9.36^{\mathrm{a}}$ & $76.17 \pm 15.57^{b}$ & $68.89 \pm 3.80^{\mathrm{b}}$ & $52.08 \pm 17.78^{\mathrm{c}}$ & $9.11 \pm 7.88^{\mathrm{d}}$ & $1.11 \pm 0.52^{\mathrm{d}}$ & $0.80 \pm 0.17^{\mathrm{d}}$ \\
\hline & SP & $210.67 \pm 5.57^{\mathrm{a}}$ & $228.41 \pm 5.95^{\mathrm{a}}$ & $326.06 \pm 67.93^{b}$ & $316.88 \pm 57.26^{b}$ & $382.76 \pm 60.52^{c}$ & $457.21 \pm 68.78^{d}$ & $495.76 \pm 42.00^{\mathrm{d}}$ \\
\hline & PV & $2.79 \pm 1.04^{\mathrm{a}}$ & $3.72 \pm 1.46^{\mathrm{a}}$ & $9.80 \pm 4.88^{\mathrm{b}}$ & $16.55 \pm 10.04^{\mathrm{ab}}$ & $28.10 \pm 15.26^{\mathrm{c}}$ & $58.49 \pm 20.25^{\mathrm{d}}$ & $77.58 \pm 17.95^{\mathrm{e}}$ \\
\hline & FFA & $3.43 \pm 1.61^{\mathrm{a}}$ & $6.80 \pm 2.27^{\mathrm{ab}}$ & $7.54 \pm 1.73^{\mathrm{ab}}$ & $14.24 \pm 2.89^{\mathrm{bc}}$ & $20.99 \pm 9.23^{\mathrm{c}}$ & $59.27 \pm 10.42^{\mathrm{d}}$ & $78.17 \pm 18.88^{\mathrm{e}}$ \\
\hline & $\mathrm{AC}$ & $5.97 \pm 1.31^{\mathrm{a}}$ & $11.98 \pm 2.61^{\mathrm{a}}$ & $12.96 \pm 1.16^{\mathrm{a}}$ & $23.13 \pm 4.20^{\mathrm{b}}$ & $25.91 \pm 2.35^{\mathrm{b}}$ & $78.86 \pm 9.57^{\mathrm{c}}$ & $96.42 \pm 16.78^{\mathrm{d}}$ \\
\hline & HV & $7.61 \pm 1.00^{\mathrm{a}}$ & $14.43 \pm 2.61^{\mathrm{ab}}$ & $15.41 \pm 1.16^{\mathrm{b}}$ & $25.58 \pm 4.20^{\mathrm{c}}$ & $28.36 \pm 2.35^{\mathrm{c}}$ & $81.31 \pm 9.57^{\mathrm{d}}$ & $98.87 \pm 16.78^{\mathrm{e}}$ \\
\hline \multirow[t]{6}{*}{$\mathrm{F}$} & IV & $82.35 \pm 7.56^{\mathrm{a}}$ & $36.35 \pm 10.41^{\mathrm{b}}$ & $24.22 \pm 3.87^{\mathrm{c}}$ & $19.27 \pm 5.38^{\mathrm{c}}$ & $4.54 \pm 1.38^{\mathrm{d}}$ & $0.80 \pm 0.36^{\mathrm{e}}$ & $0.58 \pm 0.11^{\mathrm{e}}$ \\
\hline & SP & $183.54 \pm 5.95^{\mathrm{a}}$ & $312.37 \pm 8.42^{\mathrm{b}}$ & $360.45 \pm 32.16^{\mathrm{c}}$ & $412.43 \pm 9.91^{\mathrm{d}}$ & $499.47 \pm 10.78^{\mathrm{e}}$ & $531.88 \pm 10.42^{\mathrm{f}}$ & $581.99 \pm 37.22^{\mathrm{g}}$ \\
\hline & PV & $2.41 \pm 0.95^{\mathrm{a}}$ & $6.16 \pm 2.69^{\mathrm{a}}$ & $9.13 \pm 3.18^{\mathrm{a}}$ & $21.44 \pm 9.28^{\mathrm{b}}$ & $29.57 \pm 13.39^{\mathrm{b}}$ & $54.22 \pm 18.77^{\mathrm{c}}$ & $71.92 \pm 16.64^{\mathrm{d}}$ \\
\hline & FFA & $3.02 \pm 1.40^{\mathrm{a}}$ & $10.22 \pm 3.96^{\mathrm{b}}$ & $10.26 \pm 2.74^{b}$ & $18.64 \pm 3.79^{b c}$ & $22.79 \pm 6.73^{c}$ & $61.45 \pm 10.65^{\mathrm{d}}$ & $80.87 \pm 18.84^{\mathrm{e}}$ \\
\hline & $\mathrm{AC}$ & $5.32 \pm 1.05^{\mathrm{a}}$ & $15.50 \pm 4.81^{\mathrm{b}}$ & $15.22 \pm 3.02^{\mathrm{b}}$ & $22.15 \pm 1.39^{c}$ & $27.66 \pm 2.50^{c}$ & $84.16 \pm 10.21^{\mathrm{d}}$ & $102.90 \pm 17.90^{\mathrm{e}}$ \\
\hline & HV & $7.77 \pm 1.05^{\mathrm{a}}$ & $17.95 \pm 4.81^{\mathrm{b}}$ & $17.67 \pm 3.02^{\mathrm{b}}$ & $24.60 \pm 1.39^{\mathrm{bc}}$ & $30.11 \pm 2.50^{\mathrm{c}}$ & $86.61 \pm 10.21^{\mathrm{d}}$ & $105.35 \pm 17.91^{\mathrm{e}}$ \\
\hline \multirow[t]{6}{*}{$\mathrm{C}$} & IV & $86.98 \pm 11.85^{\mathrm{a}}$ & $85.34 \pm 8.85^{\mathrm{a}}$ & $83.99 \pm 6.16^{\mathrm{a}}$ & $68.58 \pm 16.02^{\mathrm{b}}$ & $11.11 \pm 9.64^{\mathrm{c}}$ & $1.35 \pm 0.64^{\mathrm{d}}$ & $0.98 \pm 0.22^{\mathrm{d}}$ \\
\hline & SP & $215.66 \pm 6.76^{a}$ & $220.75 \pm 3.98^{\mathrm{a}}$ & $316.99 \pm 64.23^{b}$ & $303.84 \pm 50.21^{\mathrm{b}}$ & $369.48 \pm 55.13^{\mathrm{c}}$ & $448.06 \pm 67.10^{d}$ & $485.84 \pm 41.16^{\mathrm{d}}$ \\
\hline & PV & $2.88 \pm 1.06^{\mathrm{a}}$ & $3.55 \pm 1.24^{\mathrm{a}}$ & $10.21 \pm 4.87^{\mathrm{a}}$ & $15.68 \pm 9.01^{\mathrm{ab}}$ & $26.51 \pm 13.64^{\mathrm{b}}$ & $62.59 \pm 21.66^{\mathrm{c}}$ & $83.01 \pm 19.20^{\mathrm{d}}$ \\
\hline & FFA & $3.58 \pm 1.64^{\mathrm{a}}$ & $7.22 \pm 1.16^{\mathrm{ab}}$ & $9.56 \pm 1.54^{\mathrm{b}}$ & $16.12 \pm 1.17^{\mathrm{c}}$ & $22.96 \pm 7.21^{\mathrm{d}}$ & $83.64 \pm 12.86^{\mathrm{e}}$ & $110.08 \pm 24.05^{\mathrm{f}}$ \\
\hline & $\mathrm{AC}$ & $6.38 \pm 1.11^{\mathrm{a}}$ & $10.51 \pm 1.36^{\mathrm{a}}$ & $13.19 \pm 1.59^{\mathrm{a}}$ & $23.27 \pm 5.01^{b}$ & $28.58 \pm 4.82^{\mathrm{b}}$ & $81.23 \pm 9.86^{\mathrm{c}}$ & $99.31 \pm 17.28^{\mathrm{d}}$ \\
\hline & HV & $8.01 \pm 0.98^{\mathrm{a}}$ & $12.96 \pm 1.36^{\mathrm{a}}$ & $15.64 \pm 1.59^{\mathrm{a}}$ & $25.72 \pm 5.01^{b}$ & $31.03 \pm 4.82^{\mathrm{b}}$ & $83.68 \pm 9.86^{\mathrm{c}}$ & $101.76 \pm 17.28^{d}$ \\
\hline
\end{tabular}

Different superscript within the same row indicates significant difference $(\mathrm{p}<0.05)$ in means and $U=$ Unwrapped; $Z=Z$ iploc; $\mathrm{F}=$ Foil; $\mathrm{C}=$ Fish Carton

Table 6. Mean chemical properties for different packaging materials during the period of study (December, 2015 to March, 2016).

\begin{tabular}{lllll}
\hline & \multicolumn{3}{c}{ Packaging materials } \\
\cline { 2 - 5 } Parameters & Unwrapped & Ziploc & Foil & Carton \\
\hline Iodine value & $35.02 \pm 33.97^{\mathrm{b}}$ & $42.60 \pm 36.92^{\mathrm{bc}}$ & $24.02 \pm 27.56^{\mathrm{a}}$ & $48.33 \pm 39.81^{\mathrm{c}}$ \\
Saponification value & $333.69 \pm 87.90^{\mathrm{a}}$ & $345.39 \pm 111.47^{\mathrm{a}}$ & $411.73 \pm 131.00^{\mathrm{b}}$ & $337.23 \pm 107.39^{\mathrm{a}}$ \\
Peroxide value & $22.04 \pm 21.01^{\mathrm{a}}$ & $28.15 \pm 29.63^{\mathrm{b}}$ & $27.84 \pm 26.83^{\mathrm{b}}$ & $29.20 \pm 31.69^{\mathrm{b}}$ \\
Free fatty acid & $23.47 \pm 22.62^{\mathrm{a}}$ & $27.21 \pm 28.78^{\mathrm{ab}}$ & $29.61 \pm 28.91^{\mathrm{ab}}$ & $36.17 \pm 41.06^{\mathrm{b}}$ \\
Acid value & $30.97 \pm 28.53^{\mathrm{a}}$ & $36.46 \pm 34.34^{\mathrm{ab}}$ & $38.99 \pm 36.55^{\mathrm{b}}$ & $37.50 \pm 35.54^{\mathrm{b}}$ \\
Hydroxyl value & $33.31 \pm 28.63^{\mathrm{a}}$ & $38.80 \pm 34.45^{\mathrm{ab}}$ & $41.44 \pm 36.55^{\mathrm{b}}$ & $39.83 \pm 35.65^{\mathrm{ab}}$ \\
\hline
\end{tabular}

Different superscript within the same row indicates significant difference $(p<0.05)$ in means.

wrapped in carton while the lowest value was observed in samples wrapped in foil paper as shown in Table 6 . ANOVA showed that there was significant difference $(p<0.05)$ in mean iodine value among the different packaging materials and further separation of means using DMRT showed that significant differences $(\mathrm{p}<0.05)$ existed between the different packaging materials during the period of study as shown in Table 6. Pearson's correlation analysis showed that strong negative correlations ( $\mathrm{r}$ $=-0.726$ ) existed between iodine value and other chemical parameters for the different packaging materials except samples unwrapped in foil paper.

The mean saponification value ranged from $285.00 \pm 79.27-414.87 \pm 141.75 \mathrm{mg}$ of $\mathrm{KOH} / \mathrm{g}$ of fat with the highest value in the $12^{\text {th }}$ week in samples wrapped in foil paper and lowest value in fresh samples wrapped in carton as shown in Table 4. Similarly, the saponification value increased with increasing storage period with the highest value of $581.99 \pm 37.22 \mathrm{mg}$ of $\mathrm{KOH} / \mathrm{g}$ of fat in the $12^{\text {th }}$ week and lowest value of $183.54 \pm 5.95 \mathrm{mg}$ of $\mathrm{KOH} / \mathrm{g}$ of fat in the initial (0) week of the study both in samples wrapped in foil paper as shown in Table 5. However, samples wrapped in foil paper had the highest saponification value while unwrapped samples had the lowest saponification value for all the packaging materials during the period of study (Table 6). ANOVA showed that there was significant difference $(p<0.05)$ in mean between the stor- 
age periods as well as the different packaging materials during the period of study. However, further analysis using DMRT showed that there were no significant differences $(p>0.05)$ in mean saponification value between unwrapped samples, samples wrapped in carton and Ziploc bag as shown in Table 6. The saponification value and hydroxyl value had strong positive correlations $(r=0.837)$ in mean values which were significant at 0.01 level of significant for all the packaging materials as indicated by the use of Pearson's correlation analysis.

The mean peroxide value at different time of the day was highest $\left(39.12 \pm 37.35 \mathrm{meq} \mathrm{O}_{2} / \mathrm{kg}\right.$ fat $)$ in the $4^{\text {th }}$ hour in samples wrapped in carton and lowest $\left(12.77 \pm 13.80 \mathrm{meq} \mathrm{O}_{2} / \mathrm{kg}\right.$ fat$)$ in the initial time of analysis in unwrapped samples as shown in Table 4. Peroxide value increased during the period of study from $2.41 \pm 0.95 \mathrm{meq} \mathrm{O}_{2} / \mathrm{kg}$ fat at the initial (0) week of the study in samples wrapped in foil paper to $83.01 \pm 19.20 \mathrm{meq} \mathrm{O}_{2} / \mathrm{kg}$ fat in the $12^{\text {th }}$ week in samples wrapped in carton as shown in Table 5. The highest peroxide value was observed in samples wrapped in carton, but the lowest value was observed for unwrapped samples during the study period (Table 6). ANOVA showed that significant difference $(p<0.05)$ existed in mean peroxide value between the different packaging materials and the storage period. Further analysis using DMRT revealed that there was no significant difference $(\mathrm{p}>0.05)$ between samples wrapped in foil paper, carton and Ziploc bag (Table 6). However, there were significant differences $(p<0.05)$ in mean peroxide value between the storage periods using different packaging materials as shown in Table 5. Pearson's correlation indicated that a strong positive correlation $(\mathrm{r}=0.949)$ significant at 0.01 level of probability existed between peroxide value and acid value for the different packaging materials.

The mean free fatty acid value at the different time of the day ranged from $18.09 \pm 18.62-44.12 \pm 50.33 \%$ with highest value in the $4^{\text {th }}$ hour in samples wrapped in carton and lowest value in initial hour of analysis in unwrapped samples as shown in Table 4. Free fatty acid value during the period of study had the highest value of $110.08 \pm 24.05 \%$ in the $12^{\text {th }}$ week in samples wrapped in carton and lowest value of $3.02 \pm 1.40 \%$ in the initial (0) week of the study in samples wrapped in foil paper as shown in Table 6. For all the packaging materials samples wrapped in carton had the highest free fatty acid value but unwrapped samples had the lowest value during the period of study (Table 6). ANOVA indicated a significant difference $(p<0.05)$ in mean free fatty acid value between the different time of analysis, the storage periods and between the different packaging materials during the period of study. Further analysis by the use of DMRT indicated that there was no significant difference in means between the $2^{\text {nd }}$ and $4^{\text {th }}$ week of the study for the different packaging materials (Table 5). Similarly, there was no significant difference $(p>0.05)$ in means between samples wrapped in foil paper and Ziploc bag as shown in Table 6.

The mean acid value ranged between $26.40 \pm 23.49$ $44.16 \pm 42.46 \mathrm{mg}$ of $\mathrm{KOH} / \mathrm{g}$ of fat and the highest and lowest values were observed in the $4^{\text {th }}$ hour in samples wrapped in foil paper and initial time of analysis in unwrapped samples respectively as shown in Table 4 . The highest acid value of $102.90 \pm 17.90 \mathrm{mg}$ of $\mathrm{KOH} / \mathrm{g}$ of fat was obtained in the $12^{\text {th }}$ week in samples wrapped in foil paper while the lowest value of $5.32 \pm 1.05 \mathrm{mg}$ of $\mathrm{KOH} / \mathrm{g}$ of fat was observed in the initial (0) week of the study in samples wrapped in foil paper during the period of study (Table 5).The mean acid value was highest in samples wrapped in foil paper and lowest in unwrapped samples during the study period (Table 6). ANOVA showed that there was significant difference $(p<0.05)$ in means between the hour of analysis, storage periods and packaging materials. However, further separation of means by the use of DMRT revealed that there was no significant difference $(p>0.05)$ between initial $(0)$ week, $2^{\text {nd }}$ and $4^{\text {th }}$ week for unwrapped samples, samples wrapped in carton and Ziploc bag as shown in Table 5. There was also no significant difference $(\mathrm{p}>0.05)$ in mean acid values between samples wrapped in foil paper and Ziploc bag as shown in Table 6. Perfect correlation ( $\mathrm{r}$ $=1.00$ ) was observed between acid value and hydroxyl value for all the packaging materials.

Hydroxyl had the highest mean value of $46.61 \pm 42.46$ $\mathrm{mg}$ of $\mathrm{KOH} / \mathrm{g}$ of fat in the $4^{\text {th }}$ hour in samples wrapped in foil paper and lowest value of $28.85 \pm 23.49 \mathrm{mg}$ of $\mathrm{KOH} / \mathrm{g}$ of fat in the initial hour of analysis in unwrapped samples as shown in Table 4. The hydroxyl value increased from 7.61 1.00 $105.35 \pm 17.91 \mathrm{mg}$ of $\mathrm{KOH} / \mathrm{g}$ of fat with highest value in the $12^{\text {th }}$ week of the study in samples wrapped in foil paper and lowest value in the initial (0) week of the study in samples wrapped in Ziploc bag as shown in Table 5.Samples wrapped in foil paper had the highest mean hydroxyl value but the lowest value was obtained in unwrapped samples during the period of study (Table 6). ANOVA showed that there was significant difference $(p<0.05)$ in mean hydroxyl value between the hour of analysis, storage period as well as between packaging materials. Further analysis using DMRT also showed that there was significant difference $(p<0.05)$ in means between the different storage periods for the different packaging materials during the period of study (Table 5). There was also no significant difference $(p>0.05)$ between the initial hour of analysis and $2^{\text {nd }}$ hour of analysis for samples packed in Ziploc bag as well as between the $2^{\text {nd }}$ and $4^{\text {th }}$ hour of analysis for samples wrapped in foil paper as shown in Table 4. 


\section{DISCUSSION}

The most important issue in the determination of quality of fish meat is its freshness. The loss of freshness is accompanied by decomposition. One of the ways of increasing shelf-life of the fish is to preserve it at a temperature below $0^{\circ} \mathrm{C}$ (freezing). Freezing process delays the microbial and chemical reactions but some of these reactions occur at freezing temperature (Ranken and Kill, 1993). Therefore, even if the fish is frozen immediately after being caught, freeze under desired conditions in terms of coldness and moisture of the product; still, it is not a guarantee that that will keep its qualitative characteristics for unlimited time. The rate of quality decline depends on many factors such as freezing method, temperature fluctuations and thawing methods among others (Ersoy et al., 2008; Boonsumrej et al., 2007).

The present study showed that the mean protein content decreased exponentially from the initial hour of analysis to the last hour of analysis for the different packaging materials. Similarly, the highest mean protein content was recorded for fish samples analyzed at the beginning with a significant decrease in value with increasing storage period in the cold room. Mackie (1993) study on the effects of freezing on protein reported that denaturation of protein due to freezing was the main factor responsible for tissue changes (toughness). Other reasons for protein decline are drip after thawing process, relative change of chemical compositions of the muscle (Castrillon et al., 1996). Arannilewa et al. (2005) examined the effect of freezing on crude protein of the fish Sarotherodon galilaeus during a 60 days study, the results showed that the highest crude protein value was observed in the fresh sample with a significant reduction in value at the end of the storage period. Siddique et al. (2011) and Gandotra et al. (2012) work on Puntius sp. and Labeo rohita respectively on their crude protein level during frozen storage made similar observations. They stated that the decrease in crude protein level may not be unconnected with the denaturation of fish protein associated with frozen fish. The crude protein content differed significantly for all the packaging materials and this may have result from the kind and constituent of the packaging materials. The protein content was highest in samples wrapped with carton probably because of absorption of water by the fish-carton.

The percentage moisture content was higher than the percentage recorded by Eyo (2001) but within the range previously reported by Gallagher et al. (1991). The high moisture content observed in samples wrapped in Ziploc bag and foil paper may be due to low rate of evaporation of water from the fish while the lowest moisture content observed in samples wrapped in carton may be attributed to the absorption of moisture by the carton. The moisture content increased simultaneously during the period of study with similar increase being observed at the different time of analysis with samples analyzed at the initial time having the lowest moisture content and samples analyzed at the fourth $\left(4^{\text {th }}\right)$ hour having the highest moisture value. The results were not also in agreement with observation of some other researchers (Mackie, 1993; Kandeepan and Biswas, 2007; Nazemroaya et al., 2011; Magawata and Abdulmumin, 2015) who reported that freezing can decrease the capacity of water preservation in the fish muscle and increases its toughness state that the incidence of this state is due to protein degradation and loss of flexibility property of myofibril protein. FAO (1999), stated that moisture and fat contents in fish fillets are inversely related and that their sum is approximately $80 \%$ with other components accounting for the remaining $20 \%$. Therefore, the increase in moisture content may have been influenced by the decrease in fat content during the period of study.

It appeared that there was an inverse relationship between fat and moisture contents in the samples during the period of study. This result is in agreement with previous investigation (Hassan, 2001). The mean fat content was decreasing from the highest value at the initial hour of analysis to the lowest value in the $4^{\text {th }}$ hour of analysis after the initial hour. Fat content also decreased with increasing storage period and the reduction in fat content during frozen storage could be associated with the oxidation of fat which creates undesirable changes in fats causing decrease in the quality of the product (Jalili, 2008). During this prolonged storage of fish in cold room, the fat oxidation may have occurred mainly due to losses in triglyceride fraction. Agnihotri (1988) reported that deterioration in meat lipids took place due to intermediary activities of endogenous meat enzymes leading to hydrolysis of fat. This decline in fat content in the present study was similar to the results of other researchers who studied the effect of frozen period on fish quality (Gandotra et al., 2012; Siddique et al., 2011; Arannilewa et al., 2005; Zamir et al., 1998).For the different packaging materials, unwrapped samples had the highest fat content, followed by samples wrapped in carton and the lowest value was observed in Ziploc bag. There was no significant difference in fat content between samples wrapped in carton and the unwrapped samples which may be due to the rate of fat oxidation.

Mean ash content varied significantly during the period of study; decreasing value was also observed from the highest value in samples analyzed at the initial hour to the lowest value in samples analyzed at the later hours of the day. In terms of the packaging materials, the mean ash content had the highest value in unwrapped samples which decreased significantly within the different packaging materials with the lowest value occurring in samples packed in Ziploc bag and this could have resulted from low moisture loss in samples packed in Ziploc bag. The decrease observed 
in mean ash content could be in the process of thawing because when fish thaws, some of the water content is lost and this water contains some water soluble vitamins and minerals.

A good source of instant energy that comes to mind is the carbohydrates, which also help in the body development and growth. The NFA content available in the fish sample was very low indicating that the various samples of fish analyzed are poor sources of carbohydrates (Osibona et al., 2009). The relatively low values of NFA could be due to higher values of moisture and relatively high value of protein contents. It could also be due to the fact that glycogen does not contribute much to the reserves in the fish body tissue (Das and Sahu, 2001). The mean NFA content was higher in samples wrapped in foil paper than for the unwrapped samples, samples wrapped in carton and Ziploc bag; the values decreased from fresh samples (samples analyzed immediately) and the lowest value was observed at the end of the storage period. Similarly, the value decreased with increasing time (hour) of analysis. The significant difference observed between the storage periods, packaging materials as well as time of analysis may be due to array of reasons but the one that readily comes to mind in this environment is the erratic power supply and outages that makes it difficult to keep the fish under constant freezing temperature particularly between the storage periods.

The fibre content was very low in the different packaging materials for the different storage periods and at different time of the day as has been observed by several other researchers (Ryder et al., 1993; Omotosho and Olu, 1995; Nadscisa et al., 2001).

The iodine values of the samples were below the standard value of between $120-180 \mathrm{I}_{2} / 100 \mathrm{~g}$ samples; it decreased with increasing storage period and time of analysis. Prolong storage of fish in cold room was observed to reduce the level of un-saturation in fish oil and its stability due to oxidative rancidity. Memon et al. (2010) also observed gradual decrease in iodine value during the refrigeration storage of Wallago attu oil. Hence, the high mean iodine value recorded for the fresh fish samples for the different packaging materials especially samples wrapped in carton during this study suggests that before oxidative processes due to prolonged storage fresh fish sample irrespective of the packaging materials contained high level of unsaturated fish oil.

Increase in peroxide value in frozen fish during prolong storage according Ben-Gigirey et al. (1999) shows development of rancidity from oxidation of the unsaturated fatty acids present in the fish causing lipid deterioration during. Peroxide mean value increased with increasing storage period during this study, and this could be due to auto-oxidation which according to Sarma et al. (2000) may be responsible for the deterio- ration of fats and oil in fish. This result although with higher values relates to results obtained by Rostamzad et al. (2011) and Seifzadeh et al. (2012) who also observed increase in peroxide value. According to Connell (1995), when the peroxide value exceeded 10 meq $\mathrm{O}_{2} / \mathrm{kg}$ fat of fish meat, the fish meat is then considered unfit for human consumption or refused; in all the packaging materials. The values observed in all the packaging materials were within the acceptable limits in the first few weeks of study. Egan et al. (1997) suggested that the rancidity flavour occurred when peroxide values reach between $20-40 \mathrm{meq} \mathrm{O}_{2} / \mathrm{kg}$ fat. The samples should be expected to thus show rancid flavour in the $8^{\text {th }}$ week of this study for the different packaging materials.

Free fatty acid (FFA) accumulates in the tissue during frozen storage due to lipid hydrolysis especially at unstable high temperatures around -10 to $-20{ }^{\circ} \mathrm{C}$ (Pacheco-Aguilar et al., 2000; Rodriguez et al., 2007), due to lipases and phospho-lipase activity in digestive organs in muscle of fish (Okeyo et al., 2009). The free fatty acid formation due to the lipid hydrolysis provides suitable means to assess fish oil change during storage and can thus be used as food quality index according to Losada et al., (2006). In the present study the mean free fatty acid content increase with increasing time of analysis and storage time period. The obtained results were in-line with the results obtained by other researchers (Seifzadeh et al., 2012; Gandotra et al.,2012; Rodriguez et al., 2007).The free fatty acid value was lowest in unwrapped samples and in samples packed in Ziploc bag.

The mean FFA value increased with increasing time of analysis and gradually from the fresh samples till the end of the study period. Increase in acid value according Boran et al. (2006) is generally associated with the lipase activity from microorganism or biological tissue. The FFA value obtained during this study was observed to be above the recommended range of $5-8$ $\mathrm{mg} \mathrm{KOH} / \mathrm{g}$ for fish oil according to Bimbo (1998) for the storage periods and time of analysis for the different packaging materials. Although there was no significant difference in the mean acid value between the packaging materials, but the unwrapped fish samples had the lowest acid value which indicated better quality as compared to samples wrapped in foil paper which had the highest acid value. Memon et al. (2010) while working on Wallago attu also observed very high FFA values that exceeded this limit after 45-day of storage. The acid value increased at the same rate with the hydroxyl value during the period of the study.

The saponification value of fish oil obtained in this study was higher throughout the period of study in the different packaging materials than the standard value recommended for fish oil $(180-200 \mathrm{mg} \mathrm{KOH} / \mathrm{g})$ by AOAC, (2002). The saponification value of analyzed fish oil increased with increasing storage period and 
time of analysis, due to oxidative reactions, the low value in samples wrapped in Ziploc bag as against samples wrapped in foil paper and carton may be due to the low fat hydrolysis and oxidation rate. The hydroxyl value increased with increasing storage period and time of analysis. There was no significant difference between samples wrapped in carton, foil paper and Ziploc bag with Ziploc bag and unwrapped samples having better result in terms of the quality of the fish product.

\section{Conclusion}

Fish is regarded as a useful key component for a healthy diet in humans, having high food potential which is expected to give relief to humans from malnutrition especially in countries with low income earners in countries like Nigeria with inadequate protein in the average citizenry diet. Although, fresh fish is a healthier choice than frozen fish, but freezing helps preserve the quality of fish for an extended time, minimizing deterioration in colour, flavour and texture. So, fresh and frozen fish can be healthy choices, as long as they are properly stored and prepared. In this study frozen storage reduced the percentage protein in all the packaging materials with approximately $2.00 \%, 0.20 \%$ ash and $4.30 \%$ fat content in all the packaging materials at the end of the study period. The reduction in the nutritional value of the frozen fish was observed to be significant after two weeks of storage. Similarly, the chemical properties of the fish samples were not within the acceptable limits for the different packaging materials used, but unwrapped samples and samples wrapped in Ziploc had better chemical properties indicating better quality. However, the quality parameters analyzed showed that these quality values were below the set standards by the different food and fish regulatory bodies. Therefore, since the quality of fish decreased with increasing storage time in the cold rooms, which under normal condition where expected to keep the quality for a prolonged period of time. Wholesaler/cold room operators should be encouraged to get supplies in batches that would be sold off as quickly as possible, since the cost of running a plant/generator during the period of outages does not allow them to do so in their optimum capacities and thus maintain the accepted freezing temperature. The cold-room operators and retailers should also ensure proper handling and use of proper packaging materials after sells to the final consumers of fish product by observing sanitary and hygiene rules as this also have effect on the nutritional composition of frozen fish products, especially if they are not immediately cooked by the buyers. Finally, government should provide constant electricity supply because poor power supply is a major constraint affecting the quality of frozen fish in cold rooms.

\section{REFERENCES}

Adekoya, B. B. and Miller, J. W. (2004). Fish cage culture potential in Nigeria: an overview of national cultures. Agriculture Focus, 1(5): 10-16

Agnihotri, M.K. (1988). A comparative study on shelf life and microbial spoilage of refrigerated buffalo meat. $\mathrm{Ph} . \mathrm{D}$. Thesis submitted to INRI, Izatnagar.

Akinrotimi, O. A., Abu, O. M. G. and Aranyo, A. A. (2011). Environmental friendly aquaculture key to sustainable fish farming development in Nigeria. Continental Journal Fisheries and Aquatic Science, 5(2): 17-31.

Al-Jasser, M. S. and Al-Jasass, F. M. (2014). Study of the chemical, physical changes and microbial growth as quality measurement of fish. Annual Research and Review in Biology, 4(9): 1406-1420.

Alparslan, Y., Hasanhocaoglu, H., Metin, C. and Baygar, T. (2014). Determination of meat quality of sea bass (Dicentrarchuslabrax) sold at different selling areas. Emirates Journal of Food and Agriculture, 26(3): 293- 301.

AOCS(2011). Official methods and recommended practices of the American Oil Chemist Society (AOCS), Champaign, USA.

Andrew, A. E. (2001). Fish Processing Technology, Nigeria. University of Ilorin press, 7-8pp.

Arannilewa, S. T., Salawu, S. O., Soriagbe, A. A. and Olasalawu, B. B. (2005). Effect of storage period on the chemical, microbiological and sensory quality of frozen tilapia (Sarotherodon galilaeus). African Journal of Biotechnology, 4: 852-855.

AOAC (2005). Official methods of analysis of Analytical Chemists, $18^{\text {th }}$ edition. Association of Official Analytical Chemists (AOAC), MaryLand U.SA

Ayoola, S.O. (2010). Sustainable fish production in Africa. African Journal of Food Agriculture Nutrition and Development, 10(5): 1-5.

Babalola, D. A. Bajimi, O. and Isitor, S. U. (2015). Economic potentials of fish marketing and women empowerment in Nigeria: Evidence from Ogun State. African Journal of Food Agriculture Nutrition and Development, 15(2): 9922-9934.

Ben-Gigirey, B., De-souse, J. M., Barros-Velazquez, J. and Villa, T.G. (1999). Chemical changes and visual appearance of albacore tuna as related to frozen storage. Journal of Food science, 64(1): 20-24.

Beroum and, A. A. and Jooyandeh, H. (2010). Storage quality and chemical and structural changes of fresh and frozen-thawed fish. World Journal of Fish and Marine Sciences, 2(3): 251-253.

Bimbo, A. P. (1998). Guidelines for characterizing foodgrade fish oils. Inform, 9(5): $4-18$.

Boonsumrej, S., Chaiwanichsiri, S., Tantratian, S., Suzuki, T. and Takai, R. (2007).Effect of freezing and thawing on the quality changes of tiger shrimp (Penaeus monodon) frozen by air-blast and cryogenic freezing. Journal of Food Engineering, 80: 292-299.

Boonsupthip, W. and Heldman, D. R. (2007). Prediction of frozen food properties during freezing using product composition. Journal of Food Science, 72: 254-263.

Boran, G., Karacam, H. and Boran, M. (2006).Changes in the quality of fish oils due to storage temperature and temperature. Journal of Food Chemistry, 37: 693-698.

Castrillon, A. M., Alvarez-Pontes, E., Garcia-Arias, M. T.and Navarro, P. (1996). Influence of frozen storage 
and defrosting on the chemical and nutritional quality of sardine (Clupea pilchardus). Journal of the Science of Food and Agriculture, 70: 29-34.

Connell, J. J. (1995). Control of fish quality, 4th edition. Oxford: Fishing News Books, Ltd.

Das, S. and Sahu, B. K. (2001). Biochemical composition and calorific content of fishes and shellfishes from Rushikulya estuary, South Orissa coast of India. Indian Journal of Fisheries, 48: 297-302.

Egan, H., Krik, R.S. and Sawyer, R. (1997). Pearson's chemical analysis of food. 9th edition; 609-634 pp

Ersoy, B., Aksan, E. and Ozeren, A. (2008). The effect of thawing methods on the quality of eels (Anguilla anguilla). Food Chemistry, 111: 337-380.

Eyo, A. A. (2001). Fish processing technology in the tropics.National Institute for Freshwater Fisheries Research.University of Ilorin Press.10-70 pp.

FAO (2016). State of the World Fisheries and Aquaculture. Contributing to food security and nutrition for all. Rome 200pp.

FAO (2005). Post-harvest changes in fish. In: FAO Fisheries and Aquaculture Department, Food and Agriculture Organization, Rome, Italy. http://www.fao.org/fishery/ topic/12320/en

FAO (1999). Guidelines for the sensory evaluation of fish and shellfish in laboratories. CAC/GL, 31: 3-33.

Food and Agricultural Organization-FAO (1986). Food Analysis. Fisheries Technical Papers-T142.The production of fish meal and oil. Fisheries Industries Division, Food and Agriculture Organization of the United Nations, Rome, Italy. $248 \mathrm{pp}$.

Fraser, O. and Sumar, S. (1998). Compositional changes and spoilage in fish Nutrition. Food Science, 98: 275-279.

Gallagher, M. L., Harren, M. L and Rulifson, R. A. (1991). Variation in lipid and fatty acid contents of Atlantic croakers, stiped mullet and summer flounder. Transactions of the American Fisheries Society, 120: 614-619.

Gandotra, R., Koul, M., Gupta, S. and Sharma, S. (2012). Change in proximate composition and microbial count by low temperature preservation in fish muscle of $L a b$ eo rohita (Ham-Buch). Journal of Pharmacy and Biological Sciences, 2: 13-17.

Hassan, I. M. (2001). Fish technology. Science and food technology department; part of food technique book. EinShamas University, Egypt.76 pp.

Huis in't Veld, J. H. (1996). Microbial and biochemical spoilage of foods: an overview. International Journal Food Microbiology, 33: 1-18.

Huss, H. H., Ababouch, L. and Gram, L. (2003).Assessment and management of seafood safety and quality. Rome: FAO Fisheries Technical Paper, No. 444. 239pp.

Jalili, S. (2008). Influence of cold storage time on the protein changes and fatty acids deterioration of Rutilus frisikutum during frozen storage. $\mathrm{PhD}$ thesis, Islamiz Azad University of Tehran, Science and Research Branch, Tehran, Iran, 144 pp.

Kandeepan, G. and Biswas, S. (2007). Effect of low temperature preservation on quality and shelf life of buffalo meat. American Journal of Food Technology, 2: 126-135.

Losada, V., Barros-Velazquez, J. and Aubourg, S. P. (2006). Rancidity development in frozen fish: influence of slurry ice as preliminary chilling treatment. LWT 40: 991-999.

Mackie, I. M. (1993). The effect of freezing on flesh pro- teins. Food Reviews International, 9: 575-610.

Magawata, I. and Abdulmumin, I. (2015). Quality of frozen fish sold in some selected selling points within Katsina metropolis, Katsina state, Nigeria. Food Science and Quality Management, 37: 32 - 39.

Memon, N. N., Talpur, F. N., Sherazi, S. T. H. and Bhanger, M. I. (2010). Impact of refrigerated storage on quality of oil from freshwater Jarko (Wallago attu) Fish. Pakistan Journal of Analytical and Environmental Chemistry, 11(2): $37-43$.

Mol, S. and Tosun, S. Y. (2011). The quality of fish from retail markets in Istanbul, Turkey. Journal of Fisheries Sciences, 5(1): 16-25.

Monstad, T. (2004). Blue Whiting. In: Skjoldal, H. R., Editor. The Norwegian Sea ecosystem. Trondheim: Tapir Academic Press; 263-314pp.

Nadscisa, M. B., Irinen-Batista, L. M., Nunes, J. and Empris, M. (2001). Seasonal variation in the chemical composition of Horse mackerel (Trachurus trachurus) Brasilia Lisbon Portugal. 1499 - 005.

Nazemroaya, S., Sahari, M. A., Rezaei, M. (2011). Identification of fatty acid in mackerel (Scomberomorus commersoni) and shark (Carcharhinus dussumieri) fillets and their changes during six month of frozen storage at $-18^{\circ} \mathrm{C}$. Journal of Agricultural Science and Technology, 13: 553-566.

Okeyo, G. O., Lokuruka, M. N. I. and Matofari, J. W (2009). Nutritional composition and shelf life of the Lake Victoria Nile Perch (Lates niloticus) stored in ice. African Journal of Food Agriculture Nutrition and Development, 9(3): $901-919$.

Olokor, J. O., Ihuahi, J. A., Omojowo, F. S., Falayi, B. A. and Adelowo, E. A. (2007). Handbook of Practical Fisheries Technology. Published by Fisheries Technology Division, National Institute for Freshwater Fisheries Research (NIFFR), New Bussa, Niger State.22-29 pp.

Omotosho, J. S. and Olu, O. O. (1995). The effect of food and frozen storage on the nutrient composition of some African fishes. Revista De Biology Tropic, 43: 289-295.

Oota, L. (2012). Is Nigeria committed to fish production? Accessed online 20th October, 2012 from http:// blueprint.com/2012/07/is-nigeria-committed-to-fishproduction/

Osibona, A. O., Kusemiju, K., Akande, G. R. (2009). Proximate composition and fatty acids profile of the African Catfish, Clarias gariepinus. Acta SATECH, 3(1): 85-9.

Pacheco-Aguilar, R., Lugo-Sanchez, M. E. and RoblesBurgueno, M. R. (2000). Postmortem biochemical characteristic of Monterey sardine muscle stored at $0^{\circ} \mathrm{C}$. Journal of Food Sciences, 65: 40-47.

Ranken, M. D. and Kill, R. C. (1993). Food industries manual.23th edition, Springer Science, New York, 582 pp.

Rey, M. S., García-Soto, B., Fuertes-Gamundi, J. R., Aubourg, S. and Barros-Velázquez, J. (2012). Effect of a natural organic acid-icing system on the microbiological quality of commercially relevant chilled fish species. LWT - Food Science and Technology, 46: 217-223.

Rodriguez, A., Losada, V., Larrain, M. A., Quitral, V., Vinagre, J. and Aubourg, S. P. (2007). Development of lipid changes related to quality loss during the frozen storage of farmed Coho Salmon (Oncorhynchus kisutch). Journal of American Oil Chemist Society, 84 (8): 727-734. 
Rostamzad, H., Shabanpour, B., Shabani, A. and Shahiri, H. (2011). Enhancement of the storage quality of frozen Persian sturgeon fillets by using of ascorbic acid. Internal Food Resource Journal, 18: 109-116.

Ryder, J. M., Fletcher, G. C., Stec, M. G. and Seelye, R. J. (1993). Sensory, microbiological and chemical changes in hake stored in ice. International Journal of Food Science and Technology, 28: 169-180.

Sarma, J., Vidya, S. R. G. and Srikar, L. N. (2000). Effect of frozen storage on lipids and functional properties of proteins of dressed Indian oil sardine (Sardinella longiceps). Food Resource International, 33: 815-820.

Seifzadeh, M., Motallebi, A. A. and Mazloumi, M. T. (2012). Evaluation of fat quality in packaged common kilka fish soaked in whey protein compared with sodium alginate. Scholarly Journal of Agriculture Sciences, 2(2): 26-31.
Siddique, M. N., Hasan, M. J., Reza, M. Z., Islam, M. R., Boduruzaman, M., Forhadur, M. and Reza, S. (2011). Effect of freezing time on nutritional value of Jatpunti (Puntius sophore), Sarpunti ( $P$. sarana) and Thaisarpunti ( $P$. gonionotus). Bangladesh Research Publications Journal, 5(4): 387-392.

Tawfik. M. S. (2009). Proximate composition and fatty acids profiles in most common available fish species in Saudi market. Asian Journal of Clinical Nutrition, 1(1): 50-57.

Yagoub, S. O. (2009). Isolation of Enterobacteriaceae and Pseudomonas species from raw fish sold in fish market in Khartoum state. Journal of Bacteriology Research, 1 (7): 085-088

Zamir, M., Qasim, R. and Ullah, A. (1998). Changes in physical and chemical constituents of crab meat during storage at refrigerator temperature $\left(7 \pm 2^{\circ} \mathrm{C}\right)$. Pakistan Journal of Pharmaceutical Sciences, 11(1): 27-33. 